\title{
Biomimetic Cascade Polymer Nanoreactors for Starvation and Photodynamic Cancer Therapy
}

\author{
Shengda Liu ${ }^{1}$, Tengfei Yan ${ }^{1}$, Jianxin Sun ${ }^{2}$, Fei Li ${ }^{2}$, Jiayun Xu ${ }^{1}$, Hongcheng Sun ${ }^{1}$, Shuangjiang Yu ${ }^{1, *}$ \\ and Junqiu Liu ${ }^{1, *}$ \\ 1 Key Laboratory of Organosilicon Chemistry and Material Technology, Ministry of Education, College of \\ Material, Chemistry and Chemical Engineering, Hangzhou Normal University, Hangzhou 311121, China; \\ liushengda0801@foxmail.com (S.L.); tengfeiyan@163.com (T.Y.); xujiayun@jlu.edu.cn (J.X.); \\ sunhc@hznu.edu.cn (H.S.) \\ 2 State Key Laboratory of Supramolecular Structure and Materials, College of Chemistry, Jilin University, \\ Changchun 130012, China; jianxinsun2019@163.com (J.S.); sud716@163.com (F.L.) \\ * Correspondence: yusj@hznu.edu.cn (S.Y.); junqiuliu@jlu.edu.cn (J.L.)
}

Citation: Liu, S.; Yan, T.; Sun, J.; Li, F.;

Xu, J.; Sun, H.; Yu, S.; Liu, J.

Biomimetic Cascade Polymer Nanoreactors for Starvation and Photodynamic Cancer Therapy.

Molecules 2021, 26, 5609. https://

doi.org/10.3390/molecules26185609

Academic Editor: Huiqi Zhang

Received: 28 August 2021

Accepted: 14 September 2021

Published: 16 September 2021

Publisher's Note: MDPI stays neutral with regard to jurisdictional claims in published maps and institutional affiliations.

Copyright: (c) 2021 by the authors. Licensee MDPI, Basel, Switzerland. This article is an open access article distributed under the terms and conditions of the Creative Commons Attribution (CC BY) license (https:/ / creativecommons.org/licenses/by/ $4.0 /)$.

\begin{abstract}
The selective disruption of nutritional supplements and the metabolic routes of cancer cells offer a promising opportunity for more efficient cancer therapeutics. Herein, a biomimetic cascade polymer nanoreactor (GOx/CAT-NC) was fabricated by encapsulating glucose oxidase (GOx) and catalase (CAT) in a porphyrin polymer nanocapsule for combined starvation and photodynamic anticancer therapy. Internalized by cancer cells, the GOx/CAT-NCs facilitate microenvironmental oxidation by catalyzing endogenous $\mathrm{H}_{2} \mathrm{O}_{2}$ to form $\mathrm{O}_{2}$, thereby accelerating intracellular glucose catabolism and enhancing cytotoxic singlet oxygen $\left({ }^{1} \mathrm{O}_{2}\right)$ production with infrared irradiation. The GOx/CAT-NCs have demonstrated synergistic advantages in long-term starvation therapy and powerful photodynamic therapy (PDT) in cancer treatment, which inhibits tumor cells at more than twice the rate of starvation therapy alone. The biomimetic polymer nanoreactor will further contribute to the advancement of complementary modes of spatiotemporal control of cancer therapy.
\end{abstract}

Keywords: polymer nanocapsule; nanoreactor; starvation therapy; photodynamic therapy

\section{Introduction}

The alteration of cancer metabolic routes is a fascinating therapeutic approach to cancer treatment [1-5]. In general, the abnormal multiplication of cancer cells requires an adequate supply of nutrients and energies to sustain their existence and growth [6]. As a result, there is a rise in intracellular aerobic glycolysis, which is termed the Warburg effect, contributing to a greater sensitivity of cancer cells to alterations in glucose concentration [7-9]. Once glucose supply is interrupted, tumor growth is preferentially inhibited; thus, glucose metabolism-related cancer starvation therapy is increasingly regarded as a promising clinical translational approach [10-13]. To date, several strategies have been proposed to starve tumors by depleting glucose in cancer cells. In particular, the utilization of GOx to catalyze glucose metabolism is a proven effective anticancer strategy [14-17]. However, the upregulation of the adaptation of parallel energy supply to cancer cells may even result in a failure of starvation therapy. To extend the therapeutic effect, a complementary mode that cuts off the glucose supply to the cancer and destroys the cellular components associated with glucose metabolism was proposed.

As a complementary mode for synergistic therapy, PDT is a noninvasive method to precisely ablate local cancers through the tremendous oxidative power of reactive oxygen species (ROS) $[18,19]$. However, it is often necessary to convert the photosensitizers (PSs) into pharmaceutical formulations on account of their limited solubility $[20,21]$. In addition, the poor loading efficiency and the prior leakage behavior will further restrict their applications [22]. In recent years, covalent polymer nanocapsules with PSs as building 
blocks have been constructed for PDT, which demonstrate the advantages of easy diffusion of ${ }^{1} \mathrm{O}_{2}$, avoidance of self-quenching, and high loading of PSs [23-25]. Several approaches are available for the preparation of covalent polymer nanocapsules, among which enzymecatalyzed methods not only have the advantages of high efficiency, stability, and substrate specificity, but also allow the preparation of nanocapsules under mild conditions, which is very convenient to encapsulate natural enzymes [26].

As we know, covalent dimerization of tyrosine in a horseradish peroxidase (HRP)catalyzed system was an efficient method for enzyme-catalyzed preparation of polymers [27-29]. Herein, polymer nanocapsules with porphyrin PSs as building blocks were constructed based on HRP-catalyzed tyrosine dimerization. Then, polymer nanocapsules further encapsulated GOx and CAT to obtain a biomimetic cascade nanoreactor (GOx/CAT-NC) (Figure 1). Benefiting from the enhanced permeability and retention (EPR) effect, GOx/CAT-NCs would be selectively internalized into cancer cells. The cascade reaction of GOx/CAT-NCs promoted $\mathrm{O}_{2}$ production catalyzed by endogenous $\mathrm{H}_{2} \mathrm{O}_{2}$, therefore speeding up glucose catabolism and accelerating cytotoxic ${ }^{1} \mathrm{O}_{2}$ production under infrared irradiation, according to the following equations:

$$
\begin{gathered}
\mathrm{H}_{2} \mathrm{O}_{2} \stackrel{\text { CAT }}{\longrightarrow} \mathrm{H}_{2} \mathrm{O}+\mathrm{O}_{2} \\
\text { Glucose }+\mathrm{O}_{2} \stackrel{\text { GOx }}{\longrightarrow} \mathrm{H}_{2} \mathrm{O}_{2}+\text { Glucose Acid } \\
\mathrm{O}_{2} \stackrel{\text { GOX } / \text { CAT-NC }}{660 \mathrm{~nm}}{ }^{1} \mathrm{O}_{2}
\end{gathered}
$$

Here, CAT could regulate the hypoxic microenvironment of cancer by the catalytic degradation of endogenous $\mathrm{H}_{2} \mathrm{O}_{2}$. The generated $\mathrm{O}_{2}$ not only enhanced the glucose catabolism by GOx, strengthening the effect of starvation therapy, but also promoted the production of cytotoxic ${ }^{1} \mathrm{O}_{2}$, improving the effect of PDT. Therefore, the combined effects of long-term starvation therapy and powerful PDT in cancer treatment would effectively suppress cancer growth in a spatiotemporally regulated manner.
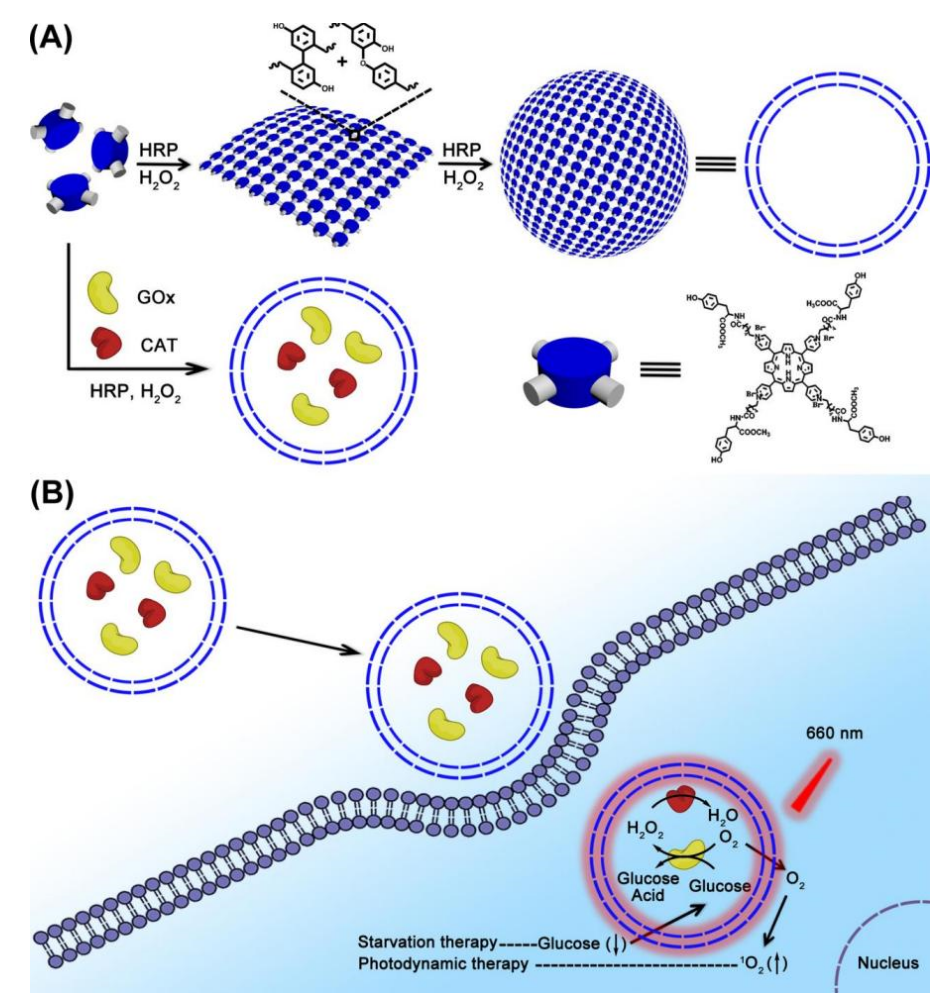

Figure 1. (A) The formation of nanocapsules and GOx/CAT-NCs. (B) The synergistic effects of GOx/CAT-NCs for starvation therapy and PDT under infrared irradiation. 


\section{Results and Discussion}

\subsection{Characterization of Polymer Nanocapsules}

Polymer nanocapsules were prepared by an enzyme-catalyzed polymerization method. In brief, polymer nanocapsules were prepared by the polymerization of porphyrin-based building blocks containing tyrosine upon HRP and $\mathrm{H}_{2} \mathrm{O}_{2}$ addition. According to the previous literature, tyrosine dimerization resulted in a characteristic fluorescence emission peak at $410 \mathrm{~nm}$ [30-32]. Therefore, we first tested the fluorescence intensity of the system before and after the reaction. As shown in Figure S7, a fluorescence emission peak was observed at $410 \mathrm{~nm}$ after polymerization; therefore, the polymers were obtained by tyrosine dimerization. Then, the structure, morphology and dimension of the polymer nanocapsules were characterized by dynamic light scattering (DLS), scanning electron microscopy (SEM), transmission electron microscopy (TEM), and atomic force microscopy (AFM). According to the DLS results, the hydrodynamic diameter of the nanocapsules was $140 \pm 60 \mathrm{~nm}$ (Figure S8). The Zeta potential results showed the nanocapsules were positively charged with $12.8 \mathrm{mV}$, which was suitable for penetrating into the cancer cells (Figure S9). As shown in Figure 2A, we could observe the spherical structure with uniform size by SEM images, and the size of which was basically consistent with the DLS results. Moreover, we had a direct view of the nanocapsules with hollow structures and thin walls by TEM (Figure 2B). The high-resolution TEM images clearly demonstrated the thin walls of nanospheres with the thickness of about $1 \mathrm{~nm}$, which were probably monolayer thin walls (Figure 2C). The AFM images further confirmed that they were spherical structures with uniform height (Figure 2D-F).
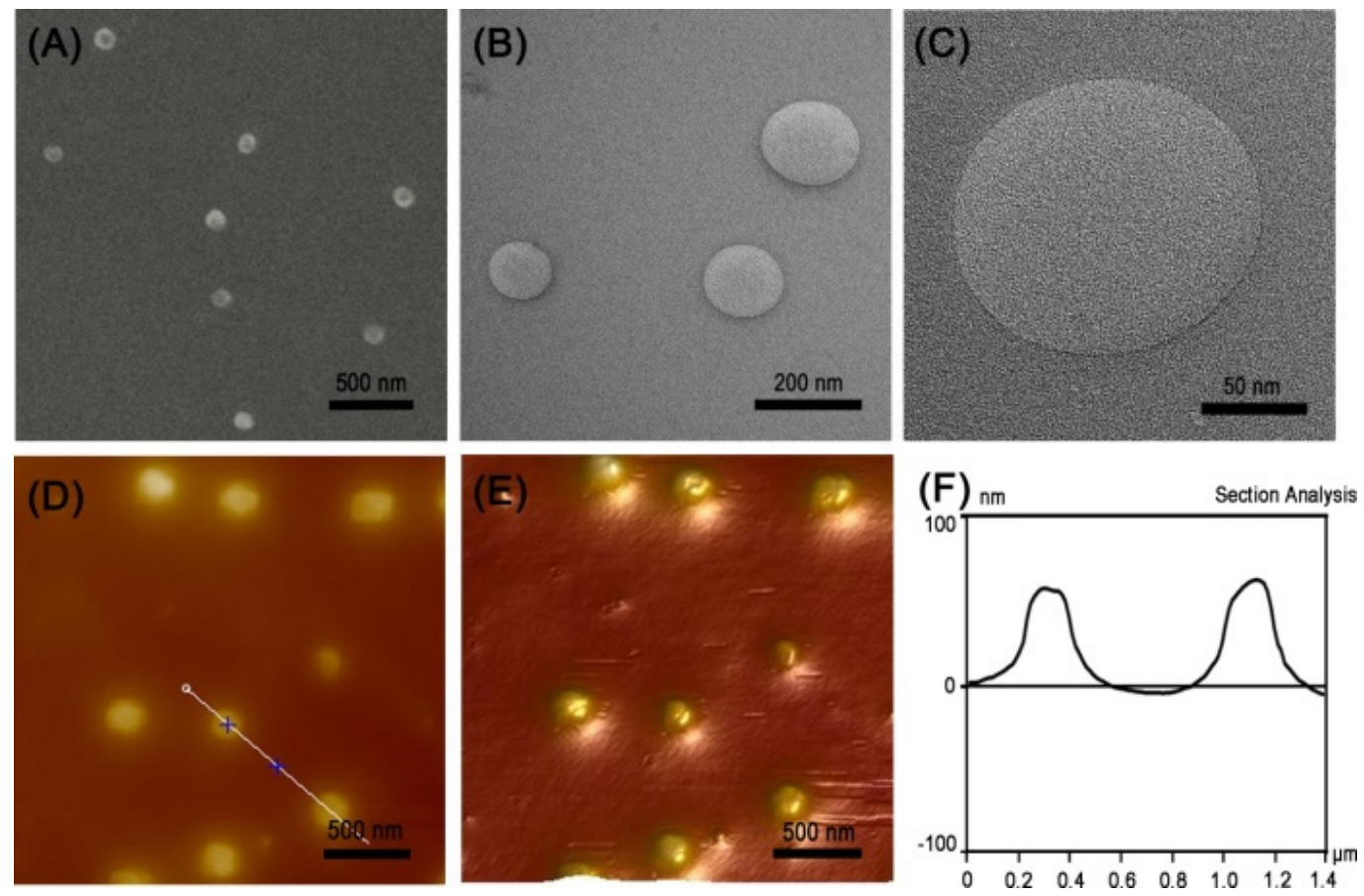

Figure 2. (A) SEM image, (B,C) TEM images, (D) AFM image, (E) 3D AFM image of the nanocapsules, and (F) associated height curve along the black line in panel D.

\subsection{Characterization of GOx/CAT-NCs}

GOx/CAT-NCs were obtained by in situ encapsulation of GOx and CAT in polymer nanocapsules. The encapsulation of CAT and GOx by polymer nanocapsules was first investigated. In the experiments, coumarin-6-carboxylic acid was modified on the CAT surface to obtain CAT-coumarin, and fluorescein isothiocyanate was modified on the GOx surface to acquire GOx-FITC, where the small molecules unreacted to the enzyme 
surface were removed by dialysis. CAT-coumarin had an excitation wavelength of $325 \mathrm{~nm}$ and an emission wavelength of $460 \mathrm{~nm}$ with blue fluorescence, while GOx-FITC showed an excitation wavelength of $495 \mathrm{~nm}$ and an emission wavelength of $517 \mathrm{~nm}$ with green fluorescence (Figure S10). Then, we encapsulated CAT-coumarin and GOx-FITC in polymer nanocapsules, and the unencapsulated enzymes were removed by ultrafiltration and centrifugation. As shown in Figure S11, we could observe the nanocapsules with blue and green fluorescence by fluorescence microscopy images, proving that both enzymes were encapsulated in the nanocapsules. After successful encapsulation of the two enzymes by nanocapsules, we tested the encapsulation efficiency of the two enzymes by the standard curve of bovine serum albumin (BSA) using Coomassie Brilliant Blue method. The result showed that the encapsulation efficiency of the enzymes was $53.1 \%$.

\subsection{Properties of Polymer Nanocapsules and GOx/CAT-NCs}

Firstly, we measured the ${ }^{1} \mathrm{O}_{2}$ production capacity of polymer nanocapsules by using the ${ }^{1} \mathrm{O}_{2}$ sensor 1, 3-diphenylisobenzofuran (DPBF) as an indicator [33,34]. The UV absorption value at $411 \mathrm{~nm}$ of DPBF alone decreased weakly under infrared irradiation. However, with the addition of polymer nanocapsules, the UV absorption value at $411 \mathrm{~nm}$ decreased sharply when the mixture was irradiated with the same power of infrared light, and the UV absorption value decreased by 0.941 within $180 \mathrm{~s}$ (Figure 3A). More specifically, the nanocapsules producing ${ }^{1} \mathrm{O}_{2}$ showed an accurate response to the illuminated state and the non-illuminated state (Figure 3B). In addition, we used $2^{\prime}, 7^{\prime}$-dichlorofluorescin diacetate (DCFH-DA) as a probe to determine the ability of polymer nanocapsules to generate ROS in real cells [35,36]. The $3 \mathrm{~T} 3$ cells were pretreated with polymer nanocapsules and then treated with DCFH-DA fluorescent probe treatment to detect intracellular ROS levels. Whether the cells were co-incubated with single DCFH-DA or with polymer nanocapsules and DCFH-DA, we could only observe very weak fluorescence. While the cells co-incubated with DCFH-DA and polymer nanocapsules were irradiated with infrared light, we observed extremely strong fluorescence (Figure 3E). The results demonstrated that ROS could be generated in real cells by porphyrin-based polymer nanocapsules under infrared irradiation.

Furthermore, the catalytic ability of GOx/CAT-NCs was studied. As shown in Figure $3 \mathrm{C}$, the $\mathrm{pH}$ value of the GOx/CAT-NCs solution without glucose treatment was maintained at about 6.81. In contrast, the addition of glucose to the GOx/CAT-NCs solution resulted in a dramatic decrease of the solution $\mathrm{pH}$ value (from 6.81 to 4.54 ) due to the catabolism of glucose by GOx and the generation of gluconic acid. Moreover, the dissolved oxygen content in the solution was monitored with the addition of glucose or $\mathrm{H}_{2} \mathrm{O}_{2}$ to the GOx/CAT-NCs solution, respectively. The dissolved oxygen content of the GOx/CAT-NCs solution alone was very stable at $5.8 \mathrm{mg} \mathrm{L}^{-1}$. When $\mathrm{H}_{2} \mathrm{O}_{2}$ was added, the dissolved oxygen content of the solution increased in a short time, rising to $19.2 \mathrm{mg} \mathrm{L}^{-1}$ within $300 \mathrm{~s}$, because the $\mathrm{CAT}$ in the nanocapsules could decompose $\mathrm{H}_{2} \mathrm{O}_{2}$ into $\mathrm{O}_{2}$. When glucose was added, the dissolved oxygen content of the solution decreased shortly, dropping to $0 \mathrm{mg} \mathrm{L}^{-1}$ within $300 \mathrm{~s}$, because of a process of oxygen consumption by the decomposition of glucose by the GOx in the nanocapsules (Figure 3D). The above results indicated that GOx/CAT-NCs had the catalytic activity of both CAT and GOx. 
(A)

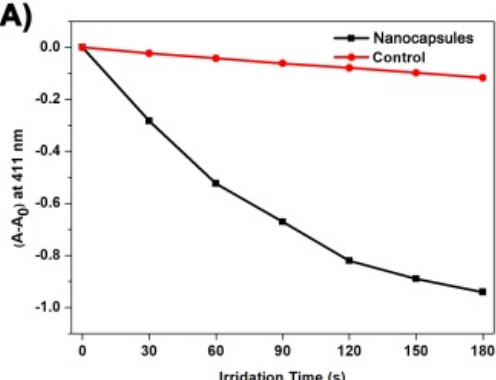

(C)

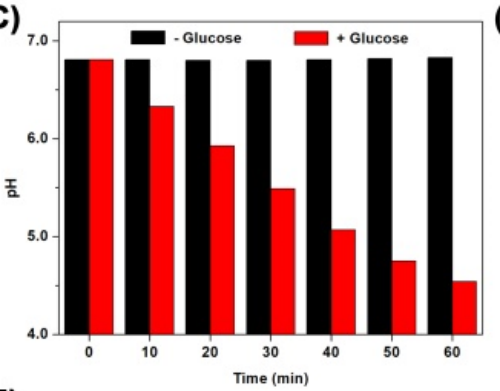

(E)

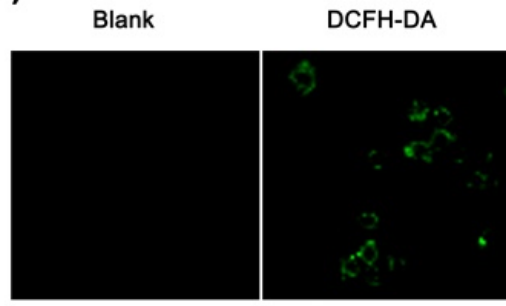

(B)

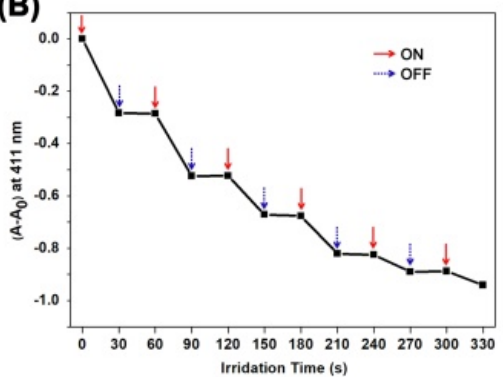

(D)

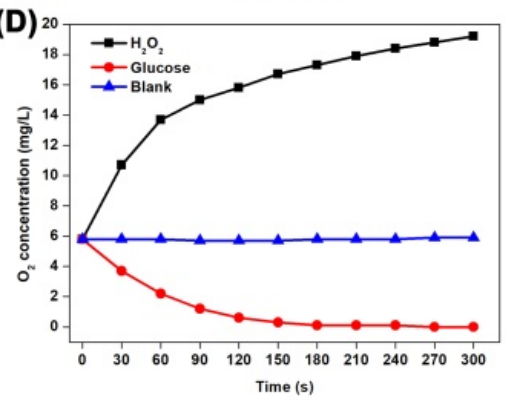

DCFH-DA +Nanocapsules

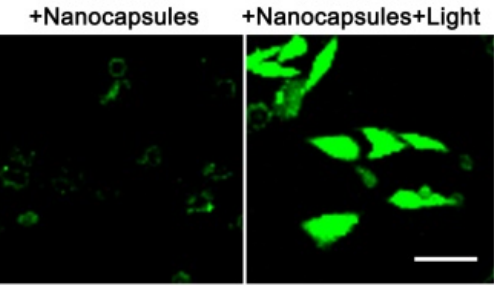

Figure 3. (A) The DPBF UV changes in the absence and presence of nanocapsules under infrared irradiation. (B) The DPBF UV changes in response of OFF-ON irradiation. (C) The $\mathrm{pH}$ value changes of GOx/CAT-NCs solution in the absence and presence of glucose. (D) The $\mathrm{O}_{2}$ concentration changes of GOx/CAT-NCs solution in the presence of $\mathrm{H}_{2} \mathrm{O}_{2}$ or glucose. (E) The CLSM images of $3 \mathrm{~T} 3$ cells with various treatments. The scale bar is $20 \mu \mathrm{m}$.

\subsection{In Vitro Anticancer Effects of GOx/CAT-NCs}

In order to investigate the uptake of the polymer nanocapsules by the cancer cells, we monitored the cell uptake process by using confocal laser microscopy (CLSM). As observed in Figure 4A, when the polymer nanocapsules were co-cultured with MCF-7 cells, red fluorescence belonging to the polymer nanocapsules was found in the cytoplasm of MCF-7 cells, indicating that the polymer nanocapsules could enter the cells by endocytosis. A prerequisite for polymer nanocapsules as carriers to be anticancer was that they were non-toxic to cells. Therefore, the toxicity of the nanocapsules was examined by 3-(4, 5-dimethylthiazol-2-yl)-2, 5-diphenyltetrazolium bromide (MTT) assay. After different concentrations of nanocapsules were co-cultured with cells, the cell survival rate was above $90.0 \%$, which showed that the nanocapsules at low concentrations were almost non-toxic to cells (Figure 4B). Then, the cytotoxicity of polymer nanocapsules, GOx/CAT-NCs, polymer nanocapsules under infrared irradiation and GOx/CAT-NCs under infrared irradiation was measured, respectively. In all experiments, polymer nanocapsules and GOx/CAT-NCs at different concentrations were co-cultured with MCF-7 cells. In the experiments of PDT and synergistic treatment of starvation and photodynamics, the controls were exposed to infrared light for an additional $5 \mathrm{~min}$. The cell survival rate reduced to $80.5 \%$, when GOx/CAT-NCs $(1 \mu \mathrm{M})$ were co-cultured with MCF-7 cells without infrared irradiation for starvation therapy alone. The cell survival rate reduced to $44.4 \%$, when polymer nanocapsules $(1 \mu \mathrm{M})$ were co-cultured with MCF-7 cells after infrared irradiation for PDT alone. After infrared irradiation, GOx/CAT-NCs $(1 \mu \mathrm{M})$ co-cultured with MCF-7 cells reached a minimum cell survival rate of $31.9 \%$, suggesting that starvation therapy 
and PDT in the system had a synergistic effect on cancer treatment (Figure 4B). Finally, we also used flow cytometry to determine apoptosis rates during starvation treatment, photodynamic treatment and synergistic treatment with starvation and photodynamics. The total mortality and apoptosis rates were $1.8 \%, 4.8 \%$, and $15.8 \%$ for control MCF-7 cells, MCF-7 cells co-incubated with polymer nanocapsules and MCF-7 cells co-incubated with GOx/CAT-NCs, respectively, which were not exposed to infrared light. When exposed to infrared light, the MCF-7 cells alone had a combined mortality and apoptosis rate of $2.5 \%$, which was almost unchanged. After infrared irradiation, MCF-7 cells co-cultured with polymer nanocapsules showed a rapid increase to the combined mortality and apoptosis rate of $21.8 \%$. When co-culturing the MCF-7 cells with the GOx/CAT-NCs under infrared irradiation, the combined mortality and apoptosis rate rose sharply and increased to $35.5 \%$, which showed the highest cell mortality and apoptosis rate and best treatment effect (Figure $4 \mathrm{C}$ ). The in vitro results further demonstrated the distinct advantages of GOx/CAT-NCs in synergistic cancer therapy compared to single starvation therapy or PDT.

(A)
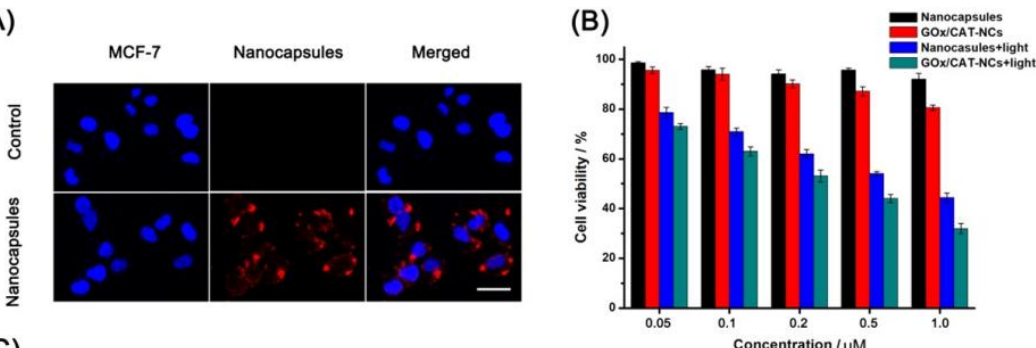

(C)

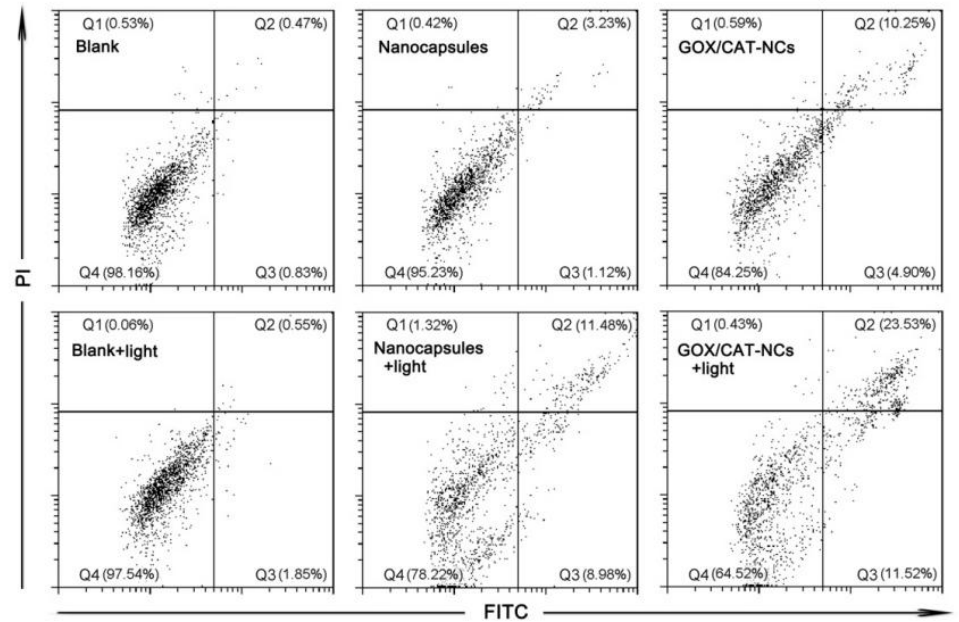

Figure 4. (A) The CLSM images of untreated MCF-7 cells and MCF-7 cells after incubation with nanocapsules, cell nuclei stained with Hoechst (blue channel). The scale bar is $50 \mu \mathrm{m}$. (B) MTT assay of the MCF-7 cells with various treatments. (C) Flow cytometry analysis of the MCF-7 cells with various treatments.

\section{Experimental Section}

\subsection{Synthesis of Porphyrin-Based Building Block}

The 4-pyridinecarboxaldehyde $(30.0 \mathrm{mmol})$ and pyrrole $(30.0 \mathrm{mmol})$ were added to $150.0 \mathrm{~mL}$ propionic acid at reflux for $3 \mathrm{~h}$. After stopping heating and cooling to room temperature, the propionic acid solvent was removed by distillation under reduced pressure. Compound 1 was obtained by multiple recrystallization of the precipitate in ethanol, with a yield of $23 \% .{ }^{1} \mathrm{H} \mathrm{NMR}\left(500 \mathrm{MHz}, \mathrm{CDCl}_{3}, 25^{\circ} \mathrm{C}\right) \delta(\mathrm{ppm}): \delta 9.07(\mathrm{~d}, 8 \mathrm{H}), 8.86(\mathrm{~s}, 8 \mathrm{H}), 8.17$ $(\mathrm{d}, 8 \mathrm{H}),-2.75(\mathrm{~s}, 2 \mathrm{H})$. ESI-MS: $m / z 619.2\left([\mathrm{M}+\mathrm{H}]^{+}\right)$.

Compound $1(0.32 \mathrm{mmol})$ and 6-bromohexanoic acid $(12.80 \mathrm{mmol})$ were placed in a flask and refluxed for $24 \mathrm{~h}$ with $80.0 \mathrm{~mL} \mathrm{~N}, \mathrm{~N}$-dimethylformamide (DMF). After cooling to room temperature, the crude product was obtained by filtering and collecting the filter 
cake. Compound 2 was obtained by repeatedly washing the filter cake with chloroform and finally collecting the cake, with a yield of $41 \% .{ }^{1} \mathrm{H} \mathrm{NMR}\left(500 \mathrm{MHz}, \mathrm{DMSO}, 25{ }^{\circ} \mathrm{C}\right) \delta$ (ppm): $\delta 12.16(\mathrm{~s}, 4 \mathrm{H}), 9.62(\mathrm{~d}, 8 \mathrm{H}), 9.26(\mathrm{~s}, 8 \mathrm{H}), 9.05(\mathrm{~d}, 8 \mathrm{H}), 4.99(\mathrm{~m}, 8 \mathrm{H}), 2.40(\mathrm{~m}, 8 \mathrm{H})$, 2.35-2.28 (m, 8H), 1.79-1.73 (m, 8H), 1.67-1.60 (m, 8H), -3.08 (s, 2H). ESI-MS: $m / z 1075.5$ $\left([\mathrm{M}-4 \mathrm{Br}-3 \mathrm{H}]^{+}\right)$.

Compound 2 (0.30 mmol), methyl L-tyrosinate hydrochloride $(1.44 \mathrm{mmol})$ and benzotriazol-1-yloxytripyrroli-dinophosphonium hexafluorophosphate (PyBOP) (1.44 mmol) were placed in a flask and reacted with $10.0 \mathrm{~mL}$ anhydrous DMF and $1.0 \mathrm{~mL}$ anhydrous triethylamine (TEA) for $24 \mathrm{~h}$ at room temperature. After cooling to $4{ }^{\circ} \mathrm{C}$ and standing overnight, the crude product was obtained by filtering and collecting the filter cake. Compound 3 (porphyrin-based building block) was obtained by repeatedly washing the filter cake with methanol and finally collecting the filter cake, with a yield of $65 \%$. ${ }^{1} \mathrm{H} \mathrm{NMR}$ $\left(500 \mathrm{MHz}, \mathrm{DMSO}, 25^{\circ} \mathrm{C}\right) \delta(\mathrm{ppm}): \delta 9.54(\mathrm{~d}, 8 \mathrm{H}), 9.36(\mathrm{~s}, 4 \mathrm{H}), 9.22(\mathrm{~s}, 4 \mathrm{H}), 9.01(\mathrm{~d}, 8 \mathrm{H})$, $8.33(\mathrm{~s}, 4 \mathrm{H}), 7.05(\mathrm{~d}, 8 \mathrm{H}) 6.67(\mathrm{~d}, 8 \mathrm{H}), 4.86-5.00(\mathrm{~m}, 8 \mathrm{H}), 4.40-4.52(\mathrm{~m}, 4 \mathrm{H}), 3.60(\mathrm{~s}, 12 \mathrm{H})$, 2.76-3.00 (m, 8H), 2.18-2.30 (m, 16H), 1.62-1.74 (m, 8H), 1.44-1.56 (m, 8H), -3.08 (s, 2H). ESI-MS: $m / z 1783.8\left([\mathrm{M}-4 \mathrm{Br}-3 \mathrm{H}]^{+}\right)$.

\subsection{Preparation of Polymer Nanocapsules and GOx/CAT-NCs}

Porphyrin-based building block was dissolved in DMF solvent and a solution of $10^{-2} \mathrm{M}$ was prepared. To a total volume of $1 \mathrm{~mL}$ of aqueous system, $10 \mu \mathrm{L}$ of the above DMF solution was added to form a $10^{-4} \mathrm{M}$ aqueous solution of porphyrin-based building block. Then, $0.1 \mu \mathrm{g}$ HRP and $10^{-2} \mathrm{M} \mathrm{H}_{2} \mathrm{O}_{2}$ were added to the system and the polymer nanocapsules were obtained after standing for $60 \mathrm{~min}$.

Porphyrin-based building block was dissolved in DMF solvent and prepared as a $10^{-2} \mathrm{M}$ solution. To a total volume of $1 \mathrm{~mL}$ of aqueous system, $10 \mu \mathrm{L}$ of the above DMF solution was introduced to produce a $10^{-4} \mathrm{M}$ aqueous solution of porphyrin-based building block. Then, it was added $10 \mu \mathrm{g}$ CAT, $10 \mu \mathrm{g}$ GOx, $0.1 \mu \mathrm{g}$ HRP and $10^{-2} \mathrm{M} \mathrm{H}_{2} \mathrm{O}_{2}$ to the system and left for $60 \mathrm{~min}$ to obtain the mixture. Finally, the non-encapsulated CAT and GOx were removed by ultrafiltration centrifuge tubes $\left(\mathrm{M}_{\mathrm{W}}\right.$ : D) to obtain GOx/CAT-NCs.

\section{3. ${ }^{1} \mathrm{O}_{2}$ Production Ability of Polymer Nanocapsules}

First, ${ }^{1} \mathrm{O}_{2}$ production under irradiation was assessed. In the experiment, we added $10^{-5} \mathrm{M}$ polymer nanocapsules and $50 \mu \mathrm{M}$ DPBF to the system. In the control, we only added $50 \mu \mathrm{M}$ of DPBF to the system without the addition of nanocapsules. Both groups were irradiated by $660 \mathrm{~nm}$ laser for the same time. Then, the response of OFF/ON irradiation to ${ }^{1} \mathrm{O}_{2}$ generation was measured. The system was the same as that previously used in the experiment. We first irradiated the system with infrared light for $30 \mathrm{~s}$ to detect the products, and then stopped the irradiation for $30 \mathrm{~s}$ for further detection of the products, which was repeated five times. At last, the ROS generation in the cells was evaluated. The 3T3 cells were first cultured for $4 \mathrm{~h}$. Subsequently, the old medium was replaced with new medium and new medium containing polymer nanocapsules, respectively. The cells continued to be cultured for $4 \mathrm{~h}$. Then, the polymer nanocapsules that did not enter the cells were washed away by washing three times with phosphate buffer $(\mathrm{pH}=7.4)$. After co-culture of nanocapsules and cells, the systems were exposed to irradiation by $660 \mathrm{~nm}$ laser for $5 \mathrm{~min}$ or none of irradiation, respectively. Next, DCFH-DA was added to the systems at $37{ }^{\circ} \mathrm{C}$ for $30 \mathrm{~min}$. The systems were identified by CLSM.

\subsection{Catalytic Activity Determination of GOx/CAT-NCs}

First, the $\mathrm{pH}$ change of GOx/CAT-NCs solution was measured without or with the addition of glucose. GOx/CAT-NCs $\left(5 \times 10^{-6} \mathrm{M}\right)$ were mixed with glucose solution (50 $\mathrm{mg} \mathrm{mL}^{-1}$ ) or distilled water, respectively. We measured the $\mathrm{pH}$ value of the solution in real time with a $\mathrm{pH}$ meter. Then, the dissolved oxygen content of GOx/CAT-NCs solution was measured with the addition of glucose or $\mathrm{H}_{2} \mathrm{O}_{2}$. The dissolved oxygen content in solution was monitored in real time by a dissolved oxygen meter when glucose 
(50 mg mL ${ }^{-1}$ ) or $\mathrm{H}_{2} \mathrm{O}_{2}(50 \mathrm{mM}$ ) was added to the solution containing in GOx/CAT-NCs $\left(5 \times 10^{-6} \mathrm{M}\right)$.

\subsection{Cell Culture and Cytotoxicity Assays}

The cells used in the experiments were MCF-7 cells and 3T3 cells from the Institute of Biochemistry and Cell Biology, Shanghai Institute for Biological Sciences, Chinese Academy of Sciences (Shanghai, China). The cell culture medium was RPMI-1640 medium containing $10 \%$ FBS and $1 \%$ antibiotics. The cell culture environment was $37^{\circ} \mathrm{C}$ with $5 \% \mathrm{CO}_{2}$ in a cell culture incubator at $37^{\circ} \mathrm{C}$.

The toxicity of polymer nanocapsules or GOx/CAT-NCs on MCF-7 cells under different conditions was examined by MTT assay. First, the MCF-7 cells were incubated in a 96-well plate for $24 \mathrm{~h}$. Then, the culture medium was removed, and different concentrations of polymer nanocapsules or GOx/CAT-NCs and the cells were co-incubated in new medium for $24 \mathrm{~h}$. The controls were irradiated by $660 \mathrm{~nm}$ laser $\left(100 \mathrm{~mW} \mathrm{~cm}^{-2}\right)$ for another $5 \mathrm{~min}$. All above systems were treated with MTT for $4 \mathrm{~h}$. Insoluble formazan crystals were generated in the well plates after MTT treatment. Finally, the medium was carefully removed and dimethyl sulfoxide (DMSO) was added to the well plates. The cell viability could be determined by measuring the absorbance of the dissolved formazan at $492 \mathrm{~nm}$.

The apoptosis rates were detected by flow cytometry. The MCF-7 cells were placed in 24-well plates and incubated with polymer nanocapsules $(1 \mu \mathrm{M})$ or GOx/CAT-NCs $(1 \mu \mathrm{M})$. The cells were incubated for $12 \mathrm{~h}$, where the controls were irradiated by a $660 \mathrm{~nm}$ laser $\left(100 \mathrm{~mW} \mathrm{~cm}^{-2}\right)$ for another $5 \mathrm{~min}$. Then, all above systems were treated with trypsin after incubation. After washing twice with PBS, the cells were stained with Annexin V-FITC/PI kit for $15 \mathrm{~min}$ and tested by flow cytometry.

\section{Conclusions}

In summary, a biomimetic cascade polymer nanoreactor, GOx/CAT-NC, was developed to improve the anticancer therapeutic efficiency with synergistic starvation and photodynamic therapy. The integration of starvation therapy and PDT was a safe cancer treatment strategy because of the ability to modulate the intracellular aerobic glycolysis and to photocontrol the toxicity of PDT in cancer cells. Furthermore, by transferring $\mathrm{H}_{2} \mathrm{O}_{2}$ to $\mathrm{O}_{2}$, the GOx/CAT-NCs could be applied to spatiotemporally controlled cancer therapy by reducing tumor hypoxia. Therefore, cutting off the glucose metabolism of cancer cells by long-term starvation therapy and damaging intracellular components by powerful PDT was a highly efficient strategy for synergistic anticancer. The biomimetic cascade nanoreactor will further contribute to the advancement of complementary modes to treat cancer more effectively despite the adverse cancer microenvironment.

Supplementary Materials: The following are available online. Figure S1. ${ }^{1} \mathrm{H}-\mathrm{NMR}$ spectrum of compound 1. Figure S2. ESI-MS analysis of compound 1. Figure S3. ${ }^{1} \mathrm{H}-\mathrm{NMR}$ spectrum of compound 2. Figure S4. ESI-MS analysis of compound 2. Figure S5. ${ }^{1} \mathrm{H}-\mathrm{NMR}$ spectrum of compound 3. Figure S6. ESI-MS analysis of compound 3. Figure S7. Fluorescence analysis of monomer and polymer nanocapsule. Figure S8. Hydrodynamic sizes of the nanocapsules in aqueous solution. Figure S9. Zeta protential distribution of the nanocapsules in aqueous solution. Figure S10. Fluorescence analysis of CAT-Coumarin and GOx-FITC. Figure S11. Fluorescence microscopy images of nanocapsules encapsulating CAT-Coumarin and GOx-FITC.

Author Contributions: Conceptualization, S.L., S.Y., and J.L.; methodology, S.L.; cell assays, J.S. and F.L.; writing—original draft preparation, S.L.; writing—review and editing, T.Y., J.X., and H.S.; supervision, J.L.; funding acquisition, H.S., S.Y., and J.L. All authors have read and agreed to the published version of the manuscript.

Funding: This work was supported by the National Key R\&D Program of China (grant no. 2020YFA0908500 and no. 2018YFA0901600) and National Natural Science Foundation of China (no. 22001054, 22075065).

Institutional Review Board Statement: Not applicable. 
Informed Consent Statement: Not applicable.

Data Availability Statement: The data presented in this study are available upon request from the corresponding author.

Conflicts of Interest: The authors declare no conflict of interest.

\section{References}

1. Schulze, A.; Harris, A.L. How Cancer Metabolism is Tuned for Proliferation and Vulnerable to Disruption. Nature 2012, 491, 364-373. [CrossRef] [PubMed]

2. Cheong, H.; Lu, C.; Lindsten, T.; Thompson, C.B. Therapeutic Targets in Cancer Cell Metabolism and Autophagy. Nat. Biotechnol. 2012, 30, 671-678. [CrossRef] [PubMed]

3. Hay, N. Reprogramming glucose metabolism in cancer: Can it be exploited for cancer therapy? Nat. Rev. Cancer 2016, 16, 635-649. [CrossRef]

4. Cairns, R.A.; Harris, I.S.; Mak, T.W. Regulation of cancer cell metabolism. Nat. Rev. Cancer 2011, 11, 85-95. [CrossRef]

5. Oronsky, B.T.; Oronsky, N.; Fanger, G.R.; Parker, C.W.; Caroen, S.Z.; Lybeck, M.; Scicinski, J.J. Follow the ATP: Tumor energy production: A perspective. Anticancer Agents Med. Chem. 2014, 14, 1187-1198. [CrossRef]

6. Tennant, D.A.; Duran, R.V.; Gottlieb, E. Targeting Metabolic Transformation for Cancer Therapy. Nat. Rev. Cancer 2010, 10, 267-277. [CrossRef] [PubMed]

7. Kim, J.; Dang, C.V. Cancer's Molecular Sweet Tooth and the Warburg Effect. Cancer Res. 2006, 66, 8927-8930. [CrossRef]

8. Vander Heiden, M.G.; Cantley, L.C.; Thompson, C.B. Understanding the Warburg effect: The Metabolic Requirements of Cell Proliferation. Science 2009, 324, 1029-1033. [CrossRef] [PubMed]

9. Koppenol, W.H.; Bounds, P.L.; Dang, C.V. Otto Warburg's Contributions to Current Concepts of Cancer Metabolism. Nat. Rev. Cancer 2011, 11, 325-337. [CrossRef]

10. Ying, H.; Kimmelman, A.C.; Lyssiotis, C.A.; Hua, S.; Chu, G.C.; Fletcher-Sananikone, E.; Locasale, J.W.; Son, J.; Zhang, H.; Coloff, J.L.; et al. Oncogenic Kras Maintains Pancreatic Tumors through Regulation of Anabolic Glucose Metabolism. Cell 2012, 149, 656-670. [CrossRef]

11. Chen, W.H.; Luo, G.F.; Lei, Q.; Hong, S.; Qiu, W.X.; Liu, L.H.; Cheng, S.X.; Zhang, X.Z. Overcoming the Heat Endurance of Tumor Cells by Interfering with the Anaerobic Glycolysis Metabolism for Improved Photothermal Therapy. ACS Nano 2017, 11, 1419-1431. [CrossRef]

12. Galluzzi, L.; Kepp, O.; Vander Heiden, M.G.; Kroemer, G. Metabolic Targets for Cancer Therapy. Nat. Rev. Drug Discov. 2013, 12, 829-846. [CrossRef]

13. Shibuya, K.; Okada, M.; Suzuki, S.; Seino, M.; Seino, S.; Takeda, H.; Kitanaka, C. Targeting the Facilitative Glucose Transporter GLUT1 Inhibits the Self-Renewal and Tumor-Initiating Capacity of Cancer Stem Cells. Oncotarget 2014, 6, 651-661. [CrossRef]

14. Guo, S.; Kohane, D.S. Nanoparticulate cancer-starvation therapy. Chem 2017, 2, 162-170. [CrossRef]

15. Zhang, C.; Ni, D.; Liu, Y.; Yao, H.; Bu, W.; Shi, J. Magnesium silicide nanoparticles as a deoxygenation agent for cancer starvation therapy. Nat. Nanotechnol. 2017, 12,378. [CrossRef]

16. Selwan, E.M.; Finicle, B.T.; Kim, S.M.; Edinger, A.L. Attacking the Supply Wagons to Starve Cancer Cells to Death. FEBS Lett. 2016, 590, 885-907. [CrossRef] [PubMed]

17. Kim, S.M.; Roy, S.G.; Chen, B.; Nguyen, T.M.; McMonigle, R.J.; McCracken, A.N.; Zhang, Y.L.; Kofuji, S.; Hou, J.; Selwan, E.; et al. Targeting Cancer Metabolism by Simultaneously Disrupting Parallel Nutrient Access Pathways. J. Clin. Investig. 2016, 126, 4088-4102. [CrossRef] [PubMed]

18. Yang, B.; Chen, Y.; Shi, J. Reactive oxygen species (ROS)-based nanomedicine. Chem. Rev. 2019, 119, 4881-4985. [CrossRef] [PubMed]

19. Allison, R.R.; Sibata, C.H. Oncologic photodynamic therapy photosensitizers: A clinical review. Photodiagn. Photodyn. Ther. 2010, 7, 61-75. [CrossRef] [PubMed]

20. Ochsner, M. Photophysical and Photobiological Processes in the Photodynamic Therapy of Tumours. J. Photochem. Photobiol. B 1997, 39, 1-18. [CrossRef]

21. Brown, S.B.; Brown, E.A.; Walker, I. The Present and Future Role of Photodynamic Therapy in Cancer Treatment. Lancet Oncol. 2004, 5, 497-508. [CrossRef]

22. Lismont, M.; Dreesen, L.; Wuttke, S. Metal-Organic Framework Nanoparticles in Photodynamic Therapy: Current Status and Perspectives. Adv. Funct. Mater. 2017, 27, 1606314. [CrossRef]

23. Hota, R.; Baek, K.; Yun, G.; Kim, Y.K.; Jung, H.; Park, K.M.; Yoon, E.; Joo, T.; Kang, J.; Park, C.G.; et al. Self-Assembled, Covalently Linked, Hollow Phthalocyanine Nanospheres. Chem. Sci. 2013, 4, 339-344. [CrossRef]

24. Roy, I.; Shetty, D.; Hota, R.; Baek, K.; Kim, J.; Kim, C.; Kappert, S.; Kim, K. A multifunctional subphthalocyanine nanosphere for targeting, labeling, and killing of antibiotic-resistant bacteria. Angew. Chem. Int. Ed. 2015, 54, 15152-15155. [CrossRef] [PubMed]

25. Liu, S.; Xu, J.; Li, X.; Yan, T.; Yu, S.; Sun, H.; Liu, J. Template-Free Self-Assembly of Two-Dimensional Polymers into Nano/Microstructured Materials. Molecules 2021, 26, 3310. [CrossRef] [PubMed] 
26. Liu, S.; Huang, Z.; Li, F.; Yan, T.; Fu, S.; Tian, R.; Hou, C.; Luo, Q.; Xu, J.; Liu, J. Supramolecular polymer nanocapsules by enzymatic covalent condensation: Biocompatible and biodegradable drug-delivery systems for chemo-photothermal anticancer therapy. Polym. Chem. 2019, 10, 3566-3570. [CrossRef]

27. Wang, X.R.; Hu, J.M.; Zhang, G.Y.; Liu, S.Y. Highly selective fluorogenic multianalyte biosensors constructed via enzyme-catalyzed coupling and aggregation-induced emission. J. Am. Chem. Soc. 2014, 136, 9890-9893. [CrossRef] [PubMed]

28. Huang, Z.; Fang, Y.; Luo, Q.; Liu, S.; An, G.; Hou, C.; Lang, C.; Xu, J.; Dong, Z.; Liu, J. Construction of supramolecular polymer by enzyme-triggered covalent condensation of CB[8]-FGG-based supramonomer. Chem. Commun. 2016, 52, 2083-2086. [CrossRef] [PubMed]

29. Zhao, L.; Zou, H.; Zhang, H.; Sun, H.; Wang, T.; Pan, T.; Li, X.; Bai, Y.; Qiao, S.; Luo, Q.; et al. Enzyme-Triggered Defined Protein Nanoarrays: Efficient Light-Harvesting Systems to Mimic Chloroplasts. ACS Nano 2017, 11, 938-945. [CrossRef]

30. Harms, G.S.; Pauls, S.W.; Hedstrom, J.F.; Johnson, C.K. Fluorescence and rotational dynamics of dityrosine. J. Fluoresc. 1997, 7, 283-292. [CrossRef]

31. Jones, L.H.; Narayanan, A.; Hett, E.C. Understanding and applying tyrosine biochemical diversity. Mol. Biosyst. 2014, 10, 952-969. [CrossRef]

32. Giulivi, C.; Traaseth, N.J.; Davies, K.J.A. Tyrosine oxidation products: Analysis and biological relevance. Amino Acids 2003, 25, 227-232. [CrossRef] [PubMed]

33. Feng, X.; Ding, X.; Chen, L.; Wu, Y.; Liu, L.; Addicoat, M.; Irle, S.; Dong, Y.; Jiang, D. Two-dimensional artificial light-harvesting antennae with predesigned high-order structure and robust photosensitising activity. Sci. Rep. 2016, 6, 32944. [CrossRef] [PubMed]

34. Spiller, W.; Kliesch, H.; Wohrle, D.; Hackbarth, S.; Roder, B.; Schnurpfeil, G. Singlet Oxygen Quantum Yields of Different Photosensitizers in Polar Solvents and Micellar Solutions. J. Porphyr. Phthalocyanines 1998, 2, 145-158. [CrossRef]

35. Liu, S.; Tian, R.; Xu, J.; Wang, L.; Sun, J.; Jiang, X.; Wang, T.; Li, X.; Luo, Q.; Liu, J. Cucurbit[8]uril-based supramolecular nanocapsules with a multienzyme-cascade antioxidative effect. Chem. Commun. 2019, 55, 13820-13823. [CrossRef] [PubMed]

36. Han, K.; Wang, S.B.; Lei, Q.; Zhu, J.Y.; Zhang, X.Z. Ratiometric Biosensor for Aggregation-Induced Emission-Guided Precise Photodynamic Therapy. ACS Nano 2015, 9, 10268-10277. [CrossRef] [PubMed] 